\title{
Element concentrations in pelagic Sargassum along the Mexican Caribbean coast in 2018-2019
}

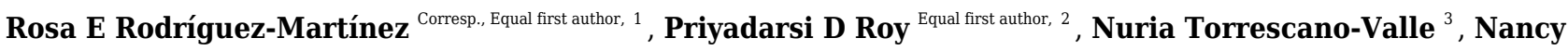 \\ Cabanillas-Terán ${ }^{3,4}$, Silvia Carrillo-Domínguez ${ }^{5}$, Ligia Collado-Vides ${ }^{6}$, Marta García-Sánchez ${ }^{1,7}$, Brigitta I van \\ Tussenbroek ${ }^{1}$ \\ 1 Instituto de Ciencias del Mar y Limnología, Universidad Nacional Autónoma de México, Puerto Morelos, Quintana Roo, México \\ 2 Instituto de Geología, Universidad Nacional Autónoma de México, Ciudad de México, Ciudad de México, México \\ 3 El Colegio de la Frontera Sur, Unidad Chetumal, Chetumal, Quintana Roo, México \\ 4 CONACYT - El Colegio de la Frontera Sur, Chetumal, Quintana Roo, México \\ 5 Departamento de Nutrición Animal, Instituto Nacional de Ciencias Médicas y Nutrición "Salvador Zubirán", Ciudad de México, Ciudad de México, México \\ 6 Department of Biological Sciences and Center for Coastal Oceans Research in the Institute of Environment, Florida International University, Miami, \\ Florida, United States \\ 7 Instituto de Ingeniería, Universidad Nacional Autónoma de México, Ciudad de México, Ciudad de México, México \\ Corresponding Author: Rosa E Rodríguez-Martínez \\ Email address: rosaer@cmarl.unam.mx
}

The massive influx of pelagic Sargassum spp. (sargasso) into the Mexican Caribbean Sea has caused major deterioration of the coastal environment and has affected the tourism industry as well as livelihoods since 2015 . Species of Sargassum have high capacity to absorb metals; thus, leachates of sargasso may contribute to contamination by potentially toxic metals when they drain into the sea and into the groundwater when dumped in adequate land deposits. Valorization of sargasso would contribute to sustainable management; therefore, knowledge on potentially toxic metal content is necessary to define possible uses of the algae. We present concentrations of 28 elements measured using a non-destructive X-ray fluorescence analyzer (XRF) in 63 samples of sargasso collected between August 2018 and June 2019 from eight localities along $~ 370 \mathrm{~km}$ long coastline of the Mexican Caribbean Sea. The sargasso tissues contained detectable concentrations of $\mathrm{Al}, \mathrm{As}, \mathrm{Ca}, \mathrm{Cl}, \mathrm{Cu}, \mathrm{Fe}, \mathrm{K}, \mathrm{Mg}, \mathrm{Mn}, \mathrm{Mo}, \mathrm{P}, \mathrm{Pb}, \mathrm{Rb}, \mathrm{S}, \mathrm{Si}, \mathrm{Sr}$, Th, U, V, and Zn. The element concentration in sargasso varied on spatial and temporal scales, which likely depended on the previous trajectory of the pelagic masses, and whether these had (or had not) passed through contaminated areas. Total arsenic concentration varied between 24-172 ppm DW, exceeding the maximum limit for seaweed intended as animal fooder (40 ppm DW) in $86 \%$ of the samples and for agricultural soils in Mexico (22 ppm DW) in $100 \%$ of the samples. For valorization, we recommend analyses of metal contents as a mandatory practice or avoiding uses for nutritional purposes. The high arsenic content is also of concern for environmental contamination of the sea and aquifer. 
1 Element concentrations in pelagic Sargassum along the Mexican Caribbean coast in 2018$2 \mathbf{2 0 1 9}$

3 Rosa E. Rodríguez-Martínez ${ }^{1 *}$, Priyadarsi D. Roy ${ }^{2}$, Nuria Torrescano-Valle ${ }^{3}$, Nancy Cabanillas4 Terán $^{3,4}$, Silvia Carrillo-Domínguez ${ }^{5}$, Ligia Collado-Vides ${ }^{6}$, Marta García-Sánchez ${ }^{1,7}$, Brigitta I. 5 van Tussenbroek ${ }^{1}$

6

$7{ }^{1}$ Instituto de Ciencias del Mar y Limnología, Universidad Nacional Autónoma de México,

8 Puerto Morelos, Quintana Roo, México

92 Instituto de Geología, Universidad Nacional Autónoma de México, Ciudad de México, Ciudad 10 de México, México

$11{ }^{3}$ El Colegio de la Frontera Sur, Unidad Chetumal, Chetumal, Quintana Roo, México

$12{ }^{4}$ CONACYT- El Colegio de la Frontera Sur, Chetumal, Quintana Roo, México

13
${ }^{5}$ Departamento de Nutrición Animal, Instituto Nacional de Ciencias Médicas y Nutrición "Salvador Zubirán", Ciudad de México, Ciudad de México, México

${ }^{6}$ Department of Biological Sciences and Center for Coastal Oceans Research in the Institute of Environment, Florida International University, Miami, Florida, United States

${ }^{7}$ Instituto de Ingeniería, Universidad Nacional Autónoma de México, Ciudad de México, Ciudad de México, México

Corresponding Author:

Rosa E. Rodríguez-Martínez

Instituto de Ciencias del Mar y Limnología, Universidad Nacional Autónoma de México, Puerto Morelos, Quintana Roo, México

Email address: rosaer@cmarl.unam.mx 
34 The massive influx of pelagic Sargassum spp. (sargasso) into the Mexican Caribbean Sea has 35 caused major deterioration of the coastal environment and has affected the tourism industry as 36 well as livelihoods since 2015. Species of Sargassum have high capacity to absorb metals; thus,

37 leachates of sargasso may contribute to contamination by potentially toxic metals when they

38 drain into the sea and into the groundwater when dumped in adequate land deposits. Valorization

39 of sargasso would contribute to sustainable management; therefore, knowledge on potentially

40 toxic metal content is necessary to define possible uses of the algae. We present concentrations

41 of 28 elements measured using a non-destructive X-ray fluorescence analyzer (XRF) in 63

42 samples of sargasso collected between August 2018 and June 2019 from eight localities along

$43 \sim 370 \mathrm{~km}$ long coastline of the Mexican Caribbean Sea. The sargasso tissues contained detectable

44 concentrations of $\mathrm{Al}, \mathrm{As}, \mathrm{Ca}, \mathrm{Cl}, \mathrm{Cu}, \mathrm{Fe}, \mathrm{K}, \mathrm{Mg}, \mathrm{Mn}, \mathrm{Mo}, \mathrm{P}, \mathrm{Pb}, \mathrm{Rb}, \mathrm{S}, \mathrm{Si}$, Sr, Th, U, V, and Zn.

45 The element concentration in sargasso varied on spatial and temporal scales, which likely

46 depended on the previous trajectory of the pelagic masses, and whether these had (or had not)

47 passed through contaminated areas. Total arsenic concentration varied between 24-172 ppm DW,

48 exceeding the maximum limit for seaweed intended as animal fooder (40 ppm DW) in $86 \%$ of

49 the samples and for agricultural soils in Mexico (22 ppm DW) in 100\% of the samples. For

50 valorization, we recommend analyses of metal contents as a mandatory practice or avoiding uses

51 for nutritional purposes. The high arsenic content is also of concern for environmental

52 contamination of the sea and aquifer.

\section{Introduction}


57 The west coast of Africa and some eastern Caribbean islands received unusual large quantities of 58 pelagic Sargassum spp. (S. fluitans (Boergesen) Boergesen and S. natans (Linnaeus) Gallion;

59 hereafter named sargasso) for the first time in 2011 (Gower, Young \& King, 2013). In

60 subsequent years, the range of massive sargasso influx extended over the Atlantic Ocean and

61 whole Caribbean Sea. Wang et al. (2019) reported more than 20 million metric tons of sargasso

62 in the open ocean in the peak month of June 2018, when the Great Atlantic Sargasso Belt

63 extended for $8,850 \mathrm{~km}$ in total length. Beaching of sargasso has caused havoc to the Caribbean

64 coastal ecosystems. Leachates and particulate organic matter from stranded decaying algal

65 masses depleted the oxygen in near shore waters and reduced visibility of the water column,

66 causing mortality of near-shore seagrasses and fauna (van Tussenbroek et al., 2017; Rodríguez-

67 Martínez et al., 2019). Onshore and near shore masses of sargasso interfered with the seaward

68 journeys of the juvenile turtles (Maurer, De Neef \& Stapleton, 2015), affected sea turtle nestings

69 (Maurer, Stapleton \& Layman, 2018) and altered the trophic structure of the sea urchin Diadema

70 antillarum in coastal marine systems (Cabanillas-Terán et al., 2019). Massive beachings also

71 enhanced beach erosion (van Tussenbroek et al., 2017). Coastal ecosystem-based tourist industry

72 is one of the major sources of income for the Caribbean countries (Langin, 2018) and the

73 potential socio-economic impacts of ecosystem degradation due to sargasso influx have yet to be

74 assessed.

75 The Mexican Caribbean coast began receiving massive amounts of sargasso during the late 2014

76 and it reached a peak in September 2015, when in the northern section of the coast between

77 Cancun and Puerto Morelos an average of $\sim 2,360 \mathrm{~m}^{3}$ of algae (mixed with sand, seagrasses and

78 other algae) arrived per km of coastline (Rodríguez-Martínez, van Tussenbroek \& Jordán-

79 Dahlgren, 2016). During 2016, and 2017, the influxes decreased, increasing again in 2018, when 
80 in the peak month May $\sim 8,793 \mathrm{~m}^{3} \mathrm{~km}^{-1}$ of algae (mixed with sand, seagrasses and other algae)

81 were removed from the same shore section (Rodríguez-Martínez et al., 2019). In the tourist

82 beaches, the algae removed from the beach and sea have been disposed in areas that are not

83 properly prepared to avoid leakage of the leachates into the aquifer. In addition, the cleaning

84 efforts have not covered the whole coastline and thousands of tons of sargasso have accumulated

85 annually along the Mexican Caribbean coast.

86 Like other brown algae, species of Sargassum (including the pelagic ones) have high capacity to

87 absorb metals and other elements (Kuyucak \& Volesky, 1988; Davis, Volesky \& Vieira, 2000).

88 This high absorption capacity is attributed to the unique mixture of polysaccharides, mainly

89 alginates, in their cell walls (Fourest \& Volesky, 1997). At present, the Sargassum spp. are used

90 for different commercial end products, such as fertilizers (Milledge \& Harvey, 2016), textiles,

91 paper and drugs (Oyesiku \& Egunyomi, 2014), as well as in the production of biogas (Wang et

92 al., 2018). They have also been increasingly used as food for animals and humans, and therefore

93 the high concentrations of contaminants, including heavy metals, may pose potential health risks

94 (Reis \& Duarte, 2018). Therefore, it is mandatory to evaluate elemental concentrations to ensure

95 that acceptable levels are maintained in terms of health regulations (e.g. Fourest \& Volesky,

96 1997). Previous studies on metal contents in sargasso, were either based on limited number of

97 samples collected mostly from a single locality (e.g. Nigeria, Oyesiku \& Egunyomi, 2014;

98 Dominican Republic, Fernández et al., 2017) or in a single season (e.g. Addico \& deGraft-

99 Johnson, 2016). Hence, it is unclear how much the metal contents can vary in the algal tissues

100 across sites and seasons and between species.

101 In this study, we estimate concentrations of 28 different elements in sargasso tissues collected

102 from the Mexican Caribbean coast, covering a linear north-south distance of $370 \mathrm{~km}$. We 
103 hypothesize that the elemental contents are variable both in time and space. The determinations

104 of metals and other elements from this study provide an essential baseline data for adequate

105 management and potential uses of sargasso.

106

107 2. Survey methodology

$108 \quad 2.1$ Study sites

109 We collected 63 samples of sargasso along the Mexican Caribbean coast, from Contoy Island, at

110 the northern extreme, to Xcalak in the south (Fig. 1). This region receives an average

111 precipitation of $\sim 1061 \mathrm{~mm} \mathrm{y}^{-1}$ and the sea-surface temperature (SST) ranges from $25.1-29.9^{\circ} \mathrm{C}$

112 (Rodríguez-Martínez et al., 2010). The Yucatán current, a major branch of the Caribbean

113 Current, transports the pelagic algal masses parallel to the Mexican Caribbean coastline. Easterly

114 trade-winds dominate this region during the summer and mild cold fronts occur during the winter

115 season. Trade-winds transport the superficial waters towards the shore, importing the pelagic

116 masses of sargasso towards the coast.

117 The coastal environment consists of beaches, rocky shores, seagrass beds, coral reefs,

118 mangroves, jungle and underground rivers (Hernández-Arana et al., 2015). All these ecosystems

119 provide services to the tourism industry, a crucial component of the regional economy (Spalding

120 et al., 2017). In the karstic Yucatan peninsula, the freshwater aquifer and seawater are constantly

121 interacting; especially near the coast (Hernández-Terrones et al., 2011; Hernández-Terrones et

122 al., 2015). This region has no other industry besides tourism. At present, this region has the

123 highest number of hotel rooms in Mexico and the number of rooms has increased from 3,206 in

1241975 to 100,986 in 2017 (SEDETUR, 2019). Similarly, the resident population grew almost 15 - 
125 folds, from less than 100,000 in 1970 to 1,501,785 in 2015 (INEGI, 2015). This rapid urban

126 development has caused coastal pollution through influx of nutrients (Carruthers, van

127 Tussenbroek \& Dennison, 2005; Hernández-Terrones et al., 2011; Baker, Rodríguez-Martínez \&

128 Fogel, 2013; van Tussenbroek et al., 2017), sewage (Metcalfe et al., 2011), and some metals (e.g.

129 Lead, see Whelan et al., 2011) into the coastal ecosystems.

2.2. Methodology

132

2.2.1. Field collection

133

134

135

136

137

138

139

140

141

142

143

144

145

146

147 from the sea, without any specific separation treatment. All surveys were conducted under permit 
148 PPD/DGOPA-116/14 granted by SAGARPA (Agriculture, Natural Resources and Fisheries

149 Secretariat) to B.I. van Tussenbroek.

150

151 2.2.2. Elemental analysis

152 Concentrations of 28 different elements were measured in dry samples using a Niton FXL 950

153 energy dispersive X-ray fluorescence (XRF) containing a 50kV X-ray tube of Ag and equipped

154 with a geometrically optimized large area drift defector following Quiroz-Jimenez \& Roy

155 (2017). Table S1 shows the limit of detection of these elements. The dried samples were

156 processed in the laboratory using a non-destructive sample preparation technique. Approximately

$1575-7$ dry g of each sample was placed in a plastic capsule that has a $4 \mu \mathrm{m}$ thick polypropylene X-

158 ray film on one side and the other side of the capsule was packed with synthetic flexible gauze.

159 The samples were measured in the mining $\mathrm{Cu} / \mathrm{Zn}$ mode and three different filters using the

160 internal calibration curves previously generated by comparing the results of Niton FXL with a

161 conventional XRF (e.g. Quiroz-Jiménez \& Roy, 2017). The results are expressed in parts per

162 million dry weight (ppm DW) after carrying out the analysis in five repetitions in each sample.

163 We used two different geological reference materials (Es-2, organic rich argillite and Es-4,

164 dolostone) for estimation of precision (Kiipli et al., 2000). Except for Mg, all other elements

165 have relative standard deviation (RSD) between $<1$ and 5\%. Mg concentrations show RSD of

$16626 \%$ and it is the least precise among all the analyzed elements. Some advantages of the XRF

167 analysis compared to other methodologies are that small samples are required $(\sim 5 \mathrm{~g})$, the results

168 have high precision, and it is non-destructive, permitting the same sample to be reused for other

169 studies. Also, it is less expensive and faster compared to the use of an ICP-MS. The relatively

170 high limit of detection of XRF for some elements is a disadvantage, and some potentially toxic

Peer) reviewing PDF | (2019:11:43362:1:1:CHECK 23 Jan 2020) 
171 elements may have been present in low concentrations, but were not measured (e.g. Ni and Co).

172 This technique measures concentrations independent of the chemical state of an element.

173

174 2.3. Data Analyses

175 The median of the five readings per element of each sample was calculated and used for further 176 analysis. For each element, the readings below the limit of detection ( $<$ LOD; Table S1) were

177 substituted with $\mathrm{LOD} / \sqrt{2}$ for calculation of summary statistics (Celo \& Dabek-Zlotorzynska, 178 2010). Distributions (spread of data and the median values) of the fourteen most commonly

179 found elements (e.g. Al, As, $\mathrm{Ca}, \mathrm{Cl}, \mathrm{K}, \mathrm{Mg}, \mathrm{Mn}, \mathrm{P}, \mathrm{Rb}, \mathrm{S}, \mathrm{Si}, \mathrm{Sr}$, Th and U) in sargasso tissue for 180 each sampling locality are illustrated by dot plots. Differences in the concentration of elements 181 among species and morphotypes were tested using non-parametric ANOVAs based on the 182 Kruskal-Wallis rank procedure. We constructed a heatmap using the data from fourteen elements 183 from Puerto Morelos (location 3, see Fig.1) to visualize temporal differences in concentration of 184 metals in seven different sampling periods between August 2018 and April 2019. Element 185 concentration values were Z-score-transformed across sampling times and their values above and 186 below the mean were used to generate the heatmap. The Z-value is a dimensionless quantity 187 which is defined by the following equation (Larsen \& Marx, 1986):

$188 \quad Z=(X-\mu) / \sigma$

189 Where $\mathrm{X}$ represents an individual raw score that is to be standardized, $\sigma$ is the standard deviation 190 of the population, and $\mu$ is the mean of the population.

191 All analyses were done in R (R Core Team, 2019) using packages: dplyr (Wickham et al., 2019), 192 ggplot2 (Wickham, 2009), gplots (Warnes et al., 2009), pgirmess (Giraudoux, 2013), reshape 193 (Wickham, 2018), tidyr (Wickham \& Henry, 2017), and RColorBrewer (Neuwirth, 2011). A 
194 reproducible record of all statistical analyses is available on GitHub

195 (https://github.com/rerodriguezmtz/ElementsSar). This includes all underlying data and R code 196 for all analyses.

197

198

\section{Results}

199

200

201

202

203

204

205

206

207

208

209

210

211

212

213

214

215

216

The most frequent elements in sargasso tissues, detected in $100 \%$ of the samples, were As, $\mathrm{Ca}$, $\mathrm{Cl}, \mathrm{K}, \mathrm{Mn}, \mathrm{P}, \mathrm{Rb}, \mathrm{S}, \mathrm{Si}, \mathrm{Sr}, \mathrm{Th}$, and $\mathrm{U}$. They were followed in frequency by $\mathrm{Mg}(92.1 \%$ of samples) and $\mathrm{Al}$ (58.7\% of samples) (Table 2). Other elements were found in fewer samples and they had median concentrations below the LOD: V (28.6\% of samples), Zn (12.7\% of samples), and $\mathrm{Cu}, \mathrm{Fe}, \mathrm{Mo}$ and $\mathrm{Pb}$, present in $7.9 \%$ of samples (Table 2). $\mathrm{Ba}, \mathrm{Cd}, \mathrm{Co}, \mathrm{Cr}, \mathrm{Ni}, \mathrm{Ti}, \mathrm{Y}$, and $\mathrm{Zr}$ remained below the LOD in all the samples (See Table S1 for LOD values). Some elements showed more than 5-fold difference between their minimal and maximal concentrations (ppm DW). For example, $\mathrm{Cl}$ showed 71.1-fold difference, K exhibited 23.1-fold difference, As had 7.2-fold difference, Si showed 6.5-fold difference and Ca exhibited 5.7-fold difference between their minimum and maximum values (Table 2). Concentrations of $\mathrm{P}, \mathrm{S}$ and $\mathrm{Sr}$ showed the least inter-site variability and the concentrations of $\mathrm{Al}, \mathrm{As}, \mathrm{Cl}$ and $\mathrm{K}$ showed the most inter-site variability (Fig. 2).

Among the potentially toxic elements, only As (median contents of 24-172 ppm DW) and Mn (median contents of 40-139 ppm DW) were present in all the samples (Table 2). Of all samples, $86 \%$ presented As concentrations above the maximum allowable concentration for seaweeds to be used as animal fooder under European regulations (40 ppm DW; EU, 2019), and 100\% of the samples were above the maximum allowable concentration for agricultural soils in Mexico (22 ppm DW; NOM-147-SEMARNAT-SSA1-2004). Approximately 5\% of our samples showed Cu 
217 concentrations above maximum tolerable level of dietary minerals for sheep (25 ppm DW) and 218 cattle (100 ppm DW) (McDowell, 1992). Other potentially toxic elements (e.g. Mo, Pb and Zn)

219 were detected in only $8-13 \%$ of the samples and they had median concentrations below the toxic 220 limits for agricultural soils (see Table 2 and Supplementary Table 2).

221 Concentrations of $\mathrm{As}, \mathrm{Ca}, \mathrm{Cl}, \mathrm{K}, \mathrm{Mn}, \mathrm{Rb}$ and $\mathrm{Si}$ varied significantly among sargasso

222 species/morphotypes (Fig. 2, Kruskal-Wallis test, p < 0.05; Table 3). As, Cl, K and Rb were 223 significantly higher in Sargassum natans VIII compared to S. natans I. The concentrations of Ca 224 and Si were significantly lower in S. natans VIII than in S. fluitans III and S. natans I. Similarly, 225 the concentration of Mn was higher in S. natans I compared to S. fluitans III and S. natans VIII 226 (Table 3). Contents of Al, Mg, P, S, Sr, Th and U did not vary significantly among species and 227 morphotypes $(\mathrm{KW}, \mathrm{p}>0.05$; Table 3$)$. We did not compare the concentrations of $\mathrm{Cu}, \mathrm{Fe}, \mathrm{Mo}, \mathrm{Pb}$ 228 and $\mathrm{Zn}$ statistically among the species/morphotypes as their medians remained $<$ LOD.

229 The concentrations of fourteen different elements (i.e. Al, As, Ca, Cl, K, Mg, Mn, P, Rb, S, Si, $230 \mathrm{Sr}$, Th and U) in sargasso collected at Puerto Morelos in seven different sampling periods, from 231 August 2018 to April 2019, showed considerable variability (Fig. 3). This inconsistent pattern 232 indicates absence of any seasonal tendency in the elemental concentrations.

233

\section{4. Discussion}

235 The sargasso tissues from the Mexican Caribbean had more $\mathrm{As}, \mathrm{Cu}$ and $\mathrm{Mn}$ and less $\mathrm{Cd}, \mathrm{Cr}, \mathrm{Pb}$ 236 and $\mathrm{Zn}$ compared to the chemical compositions of the algae biomass from Nigeria, Ghana and

237 Dominican Republic (Table 4). Most striking was the high variability of element concentrations 238 detected both in space (different sites along the coast) and time (different sampling months). This

239 variability is likely partially due to the pelagic nature of the sargasso, as it is the result of intake 
240 of metals while exposed to areas rich in metals, sources that in turn can vary depending on local

241 and regional dynamics. It is unlikely that heavy metals were absorbed in near-shore waters of the

242 Mexican Caribbean because this area lacks these elements in high concentrations, due to absence

243 of major industrial, mining or heavy agricultural activities in the region. In addition, the

244 absorption of metals by Sargassum thunbergii under experimental conditions was only clearly

245 noticeable after $\geq 3$ d exposure (Wu et al. 2010), whereas the residence time of sargasso in near-

246 shore Mexican waters is usually in the order of hours when it is transported from the Yucatan

247 current towards the shore. Thus, the sargasso tissues likely acquired the heavy and trace elements

248 before entering the Mexican coastal waters. Different contaminants are released into the ocean,

249 some as point sources and others more continuous, in different parts across the North Equatorial

250 Recirculation Region of the Atlantic Ocean (NERR) and the Wider Caribbean Region (as a result

251 of long-range transport). Fernandez, Singh \& Jaffe (2007) recognized the discharge of sewage,

252 mineral extracts, fertilizer and pesticide used in the agricultural sector as the principal pollution

253 sources. The pelagic masses of sargasso might have been exposed to these contaminants

254 depending on its trajectory in the ocean. The metal sequestration also involves complex

255 mechanisms of ion exchange, chelation, adsorption, and ion entrapment in polysaccharide

256 networks of the algae (Volesky \& Holan 1995). This ion entrapment, in turn, depends on the

257 affinity of some divalent metals to alginates (Haug, 1961), and $\mathrm{pH}$ of the seawater also

258 influences absorption of metals (Davis, Volesky \& Vieira, 2000). Alginates are often

259 characterized by the proportion of mannuronic $(\mathrm{M})$ and guluronic $(\mathrm{G})$ acids present in the

260 polymer (M:G ratio), which may vary among and within species. For example, Mn concentration

261 was higher in $S$. natans I, whereas Ca and Si concentrations were higher in S. fluitans III and $S$.

262 natans I, and the concentrations of $\mathrm{As}, \mathrm{Cl}, \mathrm{K}$ and $\mathrm{Rb}$ were higher in $S$. natans VIII than in $S$. 
263

264

265

266

267

268

269

270

271

272

273

274

275

276

277

278

279

280

281

282

283

284

285

natans I. Variations in the metal concentrations among the sargasso species and morphological forms may be explained by different concentrations in their tissues, but also by differences in calcifying epifauna, such as bryozoans, tube polychaeta, and crustose coralline algae (Weiss, 1968; Huffard et al., 2014). Large differences in concentrations of Si (447-2,922 ppm DW) could be explained by different abundance of diatoms and silicoflagellates present in the samples (Takahashi \& Blackwelder 1992).

Sargasso samples from the Mexican Caribbean coast contained essential macro-elements for plants, like Ca (23,723-136,146 ppm DW), K (1,990-46,002 ppm DW), Mg (<2915-13,662 ppm DW), P (228-401 ppm DW) and S (9,462-24,773 ppm DW), in addition to various microelements. Similar properties have been found in other Sargassum spp., making them adequate as complementary fertilizers as they enhance growth, seed germination and photosynthesis of crop plants on mineral-depleted soils (Sathya et al., 2010; Kumari, Kaur \& Bhatnagar, 2013; El-Din, 2015). Some micro-elements found in sargasso from Mexico, such as $\mathrm{Cu}, \mathrm{Mn}, \mathrm{Mo}$ and $\mathrm{Zn}$, are micronutrients in low concentrations, but they are potentially toxic when present in high concentrations. In this study, we detected the presence of $\mathrm{Cu}(<8-540 \mathrm{ppm} \mathrm{DW})$ and Mo $(<1-7$ ppm DW) in $7.9 \%$ of the samples, Zn $(<2-17$ ppm DW) in $12.9 \%$ of the samples and Mn (40139 ppm DW) in all the samples. Cu concentrations exceeded safely limits recommended for agricultural soils by several countries in 5\% of the samples (see Supplementary Table 2S). Similarly, about $8 \%$ of our samples contained Mo concentrations above the maximum level established for agricultural soils by Canada (i.e. 2 ppm DW), but these were below the limits established by Austria and Poland (i.e. 10 ppm DW). Mn content was above 100 ppm DW in $22 \%$ of the samples, considered toxic for some plant species, but acceptable for others that can tolerate Mn up to 5000 ppm DW (Howe, Malcolm \& Dobson, 2004). Pb (<2-3 ppm DW) could 
286 be detected only in $7.9 \%$ of the samples, due to the limitation related to LOD of XRF analysis, 287 and its concentration always remained below the toxic levels. Arsenic is of concern for the 288 usages of sargasso as complementary fertilizer for crop plants. Limits of total As allowed for 289 agricultural soils are between 15-50 ppm DW depending on the country (Supplementary Table 290 2S) (Belmonte et al., 2010), thus, continuous application of sargasso (with total As between 24291172 ppm DW) may cause accumulation of As in the soils above allowable levels. High 292 concentrations of As in soil may be toxic for the plants themselves, as it interferes with 293 photosynthesis and other metabolic processes (Påhlsson, 1989, Ruiz Huerta \& Armienta 294 Hernández, 2012).

295 Sargasso could also be considered as animal fodder due to the presence of micro- and macro296 elements, in addition to proteins, fibers and other components (Marín et al., 2009; Carrillo et al., 297 2012). However, approximately $86 \%$ of the samples had total As concentrations above the 298 maximum level (40 ppm DW) allowable in Europe for animal feed materials derived from 299 seaweed (EU, 2019). The toxicity of As depends on its chemical form, with inorganic As 300 (trivalent state As III and pentavalent state As V) considered toxic (e.g. Yuan, 2007; Circuncisão 301 et al., 2018), thus, even if total As concentrations are below $40 \mathrm{ppm} \mathrm{DW}$, it is recommendable to 302 carry out As speciation studies before using sargasso as animal fodder.

303 The (occasional) high contents of potentially toxic metals in sargasso is also a serious threat for 304 the environment. The Mexican Caribbean coast has already received millions of tons of algae 305 since late 2014. This accumulation over time, in addition to eutrophication and organic matter 306 accumulation (Carruthers, van Tussenbroek \& Dennison, 2005; Hernández-Terrones et al., 2011;

307 Baker, Rodríguez-Martínez \& Fogel, 2013; van Tussenbroek et al., 2017), is also a potential 308 source of metal contamination for this region, even though levels of some potentially toxic 
309 elements like $\mathrm{Cu}, \mathrm{Mo}, \mathrm{Zn}, \mathrm{Mn}$ and $\mathrm{Pb}$ were low. The sargasso removed from Mexican Caribbean

310 beaches is presently deposited at abandoned limestone quarries, near the coast, without any

311 treatment. The Yucatan Peninsula has a highly porous karst aquifer that is the only source of

312 freshwater in the region. The pollutants from near surface deposits can easily infiltrate into the

313 aquifer causing accumulation of As and other potentially toxic metals in the groundwater.

314 Considering that water from the aquifer flows into the ocean through underground rivers, all

315 these metals and excessive nutrients will eventually reach the marine environment (Carruthers et

316 al. 2005; Metcalfe et al. 2011; Baker et al. 2013). Prevention and mitigation measures are

317 urgently needed to ensure that the massive influx of sargasso does not harm the coastal

318 ecosystems and the tourism-based economy of countries located in the vicinity of the Great

319 Atlantic Sargassum belt, including the Mexican Caribbean. The analyses of different specimens

320 collected over longer periods and from different locations is required to obtain reliable

321 information about metal contents in tissues.

322

\section{Conclusion}

324 In countries affected by the Great Atlantic Sargassum belt, the accumulation of decomposing 325 sargasso on shores has harmed the coastal ecosystems, tourism-based economy and general

326 human well-being. The Mexican Caribbean coast has received millions of tons of sargasso since 327 late 2014, and our study concludes that the massive influx might contribute with potentially toxic elements to the coastal ecosystems, including the aquifer. We observed relatively higher values of $\mathrm{As}, \mathrm{Cu}$ and $\mathrm{Mn}$ and lower values of $\mathrm{Cd}, \mathrm{Cr}$ and $\mathrm{Pb}$ compared to similar studies in countries affected by the Sargassum belt. $\mathrm{Cu}, \mathrm{Mo}, \mathrm{Zn}, \mathrm{Mn}$ and $\mathrm{Pb}$ were present in lower contents but their accumulation over time might be a potential source of contamination in this region. Total arsenic 
332 in most samples exceeded the limit established for usage as animal fodder in Europe and for 333 agricultural soil in several countries. Further studies on As speciation are required before using

334 sargasso in food industries to determine if it complies with guidelines of international institutions

335 and organizations (i.e. FAO, WHO). Chemical analysis should also be conducted using other

336 methodologies such as an ICP-MS, with better limit of detection, before evaluating sargasso

337 usages in food, pharmaceutical and agricultural industries. Governments and industries have the

338 financial strengths, as well as the moral and legal responsibilities, to carry out regular analyses of

339 specimens collected over long periods and from different locations required for obtaining reliable

340 information about metal contents in the tissues of sargasso due to its unpredictable variability.

342 Acknowledgments

343 Special thanks to Elisa Vera Vázquez, for collecting sargasso samples from Puerto Morelos and

344 Manta México Caribe A.C. for providing samples from Blue Waters and Isla Contoy. We also

345 want to thank CEMIE-Oceano for the samples at Cozumel. Gabriela González López provided

346 logistic help during fieldwork and in laboratory and Irma Gabriela Vargas-Martinez helped in

347 XRF analysis. The authors claim no conflict of interest with this work.

349 References

350

351

352

353

354
Addico, G.N.D., deGraft-Johnson, K.A.A. 2016. Preliminary investigation into the chemical composition of the invasive brown seaweed Sargassum along the West Coast of Ghana. African Journal of Biotechnology 15: 2184-2191.DOI: 10.5897/AJB2015.15177

Baker, D.M., Rodríguez-Martínez, R.E., Fogel, M.L. 2013. Tourism's nitrogen footprint on a Mesoamerican coral reef. Coral Reefs 32: 691-699. DOI: 10.1007/s00338-013-1040-2 
355

356

357

358

359

360

361

362

363

364

365

366

367

368

369

370

371

372

373

374

375

376

377

378

379

380

381

382

383

384

385

386

387

388

389

390

391

392

393

394

395

Belmonte-Serrato, F., Romero-Díaz, A., Alonso-Sarría, F., Moreno-Brotóns, J., Rojo-López, S., 2010. Afección de suelos agrícolas por metales pesados en áreas limítrofes a explotaciones mineras del sureste de España. Papeles de Geografia 51-52: 45-54. ISSN-e: 1989-4627

Cabanillas-Terán, N., Hernández-Arana, H.A., Ruiz-Zárate, M-Á., Vega-Zepeda, A., SanchezGonzalez, A. 2019. Sargassum blooms in the Caribbean alter the trophic structure of the sea urchin Diadema antillarum. PeerJ 7:e7589. DOI: 10.7717/peerj.7589

Carrillo, S., Bahena, A., Casas, M., Carranco, M.E., Calvo, C.C., Ávila, E., Pérez-Gil, F. 2012. The alga Sargassum spp. as alternative to reduce egg cholesterol content. Cuban Journal of Agricultural Science 46: 181-186.

Carruthers, T.J.B., van Tussenbroek, B.I., Dennison, W.C. 2005. Influence of submarine springs and wastewater on nutrient dynamics of Caribbean seagrass meadows. Estuarine, Coastal and Shelf Science 64: 191-199. DOI: 10.1016/j.ecss.2005.01.015

Celo, V., Dabek-Zlotorzynska, E. 2010. Concentration and source origin of trace metals in PM 2.5 collected at selected Canadian sites within the Canadian national air pollution surveillance program. In: Urban Airborne Particulate Matter. Springer, Berlin, Heidelberg, pp. 19-38. DOI: $10.1007 / 978-3-642-12278-1 \_2$

Circuncisão, A.R., Catarino, M.D., Cardoso, S.M., Silva, A.M.S. 2018. Minerals from macroalgae origin: health benefits and risks for consumers. Marine Drugs 16, 400: 2-30. DOI: 10.3390/md16110400

Davis, T.A., Volesky, B., Vieira, R.H.S.F. 2000. Sargassum seaweed as biosorbent for heavy metals. Water Research 34: 4270-4278. DOI: 10.1016/S0043-1354(00)00177-9

El-Din, S.M.M. 2015. Utilization of seaweed extracts as bio-fertilizers to stimulate the growth of wheat seedlings. The Egyptian Journal of Experimental Biology (Botany) 11: 31-39. ISSN: 1687-7497

EU (European Union). 2019. Commission Regulation (EU) 2019/1869 of 7 November 2019 amending and correcting Annex I to Directive 2002/32/EC of the European Parliament and of the Council as regards maximum levels for certain undesirable substances in animal feed. Retrieved from. http:// https://eur-lex.europa.eu/eli/reg/2019/1869/oj (Date accessed 29.12.2019).

Fernández, F., Boluda, C.J., Olivera, J., Guillermo, L.A. 2017. Análisis elemental prospectivo de la biomasa algal acumulada en las costas de la República Dominicana durante 2015. Centro Azúcar 44: 11-22. ISSN: 223.4861

Fernandez, A., Singh, A., Jaffé, R. 2007. A literature review on trace metals and organic compounds of anthropogenic origin in the Wider Caribbean Region. Marine Pollution Bulletin 54: 1681-1691. DOI: 10.1016/j.marpolbul.2007.08.007

Fourest, E., Volesky, B. 1997. Alginate properties and heavy metal biosorption by marine algae. Applied Biochemistry and Biotechnology 67:215-226. DOI: 10.1007/BF02788799

Galán, E., Romero, A. 2008. Contaminación de suelos por metales pesados. Revista de la Sociedad Española de Mineralogía 10: 48-60. ISSN 1885-7264

Giraudoux, P. 2013. Pgirmess: data analysis in ecology. R package version 1.5.7. [http://CRAN.R-project.org/package=pgirmess]. 
396 397

398 399

400

401

402

403

404

405

406

407

408

409

410

411

412

413

414

415

416

417

418

419

420

421

422

423

424

425

426

427

428

429

430

431

432

433

434

435

Gower, J., Young, E., King, S. 2013. Satellite images suggest a new Sargassum source region in 2011. Remote Sensing Letters 4: 764-773. DOI: 10.1080/2150704X.2013.796433

Haug, A. 1961. Affinity of some divalent metals to different types of alginates. Acta Chemica Scandinavica 15: 1794-1795.

Hernández-Arana, H.A., Vega-Zepeda, A., Ruíz-Zárate, M.A., Falcón-Álvarez, L.I., LópezAdame, H., Herrera-Silveira, J., Kaster, J. 2015. Transverse Coastal Corridor: From Freshwater Lakes to Coral Reefs Ecosystems. In: Biodiversity and Conservation of the Yucatán Peninsula. Islebe GA, Calmé S, León Cortés J, Schmook B (eds), pp. 355-376. (Springer, Cham.).

Hernández-Terrones, L.M., Null, K.A., Ortega-Camacho, D., Paytan, A. 2015. Water quality assessment in the Mexican Caribbean: impacts on the coastal ecosystem. Continental Shelf Research 102: 62-72. DOI: 10.1016/j.csr.2015.04.015

Hernández-Terrones, L., Rebolledo-Vieyra, M., Merino-Ibarra, M., Soto, M., Le-Cossec, A., Monroy-Ríos, E. 2011. Groundwater pollution in a karstic region (NE Yucatan): baseline nutrient content and flux to coastal ecosystems. Water, Air, \& Soil Pollution 218: 517-528. DOI: $10.1007 / \mathrm{s} 11270-010-0664-\mathrm{X}$

Howe, P., Malcolm, H., Dobson, S. 2004. Manganese and its components: environmental aspects. World Health Organization, Geneva. ISSN 1020-6167

Huffard, C.L., von Thun, S., Sherman, A.D., Sealy, K., Smith, Jr K.L. 2014. Pelagic Sargassum community change over a 40-year period: temporal and spatial variability. Marine Biology 161: 2735-2751. DOI: 10.1007/s00227-014-2539-y

INEGI. 2015. Encuesta Intercensal 2015. Tabulados Básicos. Quintana Roo, México. INEGI. https://www.inegi.org.mx/programas/intercensal/2015/default.html\#Tabulados. Accessed 2019 Nov 11.

Kiipli, T., Batchelor, R.A., Bernal, J.P., Cowing, C., Hagel-Brunnstrom, M., Ingham, M.N. Johnson, D., Kivisilla, J., Knaack, Ch., Kump, P., Lozano, R., Michiels, D., Orlova, K., Pirrus, E., Rousseau, R.M., Ruzicka, J., Sandström, H., Willis, J.P. 2000. Seven sedimentary rock reference samples from Estonia. Oil Shale 17: 215-224.

Kumari, R., Kaur, I., Bhatnagar, A.K. 2013. Enhancing soil health and productivity of Lycopersicon esculentum Mill. using Sargassum johnstonii Setchell \& Gardner as a soil conditioner and fertilizer. Journal of Applied Phycology 25: 1225-1235.DOI: 10.1007/s10811-012-9933-y

Kuyucak, N., Volesky, B. 1988. Biosorbents for recovery of metals from industrial solutions. Biotechnology Letters 10: 137-142. DOI: 10.1007/BF01024641

Langin, K. 2018. Seaweed masses assault Caribbean islands. Science 360: 1157-1158. DOI: 10.1126/science.360.6394.1157

Larsen, R.J., Marx, M.L. 1986. An introduction to mathematical statistics and its applications. Prentice-Hall Englewood Cliffs, NJ. ISBN 978-0-321-69394-5

McDowell, L.R. 1992. Minerals in animal and human nutrition. pp. 404, Cunha, T.J. (ed.). Academic Press Inc. USA. 524 p. 
436

470

471

472

473

474

475

Marín, A., Casas-Valdez, M., Carrillo, S., Hernández, H., Monroy, A., Sanginés, L., Pérez-Gil, F. 2009. The marine algae Sargassum spp. (Sargassaceae) as feed for sheep in tropical and subtropical regions. Revista de Biologia Tropical 57: 1271-1281. ISSN 0034-7744

Maurer, A.S., De Neef, E., Stapleton, S. 2015. Sargassum accumulation may spell trouble for nesting sea turtles. Frontiers in Ecology and the Environment 13: 394-395.

Maurer, A.S., Stapleton, S.P., Layman, C.A. 2018. Impacts of the Caribbean Sargassum influx on sea turtle nesting. Proceedings of the 71st Gulf and Caribbean Fisheries Institute: 327-329.

Metcalfe, C.D., Beddows, P.A., Gold, B.G., Metcalfe, T.L., Li, H., Van Lavieren, H. 2011. Contaminants in the coastal karst aquifer system along the Caribbean coast of the Yucatan Peninsula, Mexico. Environmental Pollution 159: 991-997. DOI: 10.1016/j.envpol.2010.11.031

Milledge, J.J., Harvey, P.J. 2016. Golden Tides: Problem or Golden Opportunity? The Valorisation of Sargassum from Beach Inundations. Journal of Marine Science and Engineering 4: 60. DOI: 10.3390/jmse4030060

Neuwirth, E. 2011. R package. Version 1.0-5. http://CRAN.Rproject.org $/$ package $=$ RColorBrewer.

Oyesiku, O.O., Egunyomi, A. 2014. Identification and chemical studies of pelagic masses of Sargassum natans (Linnaeus) Gaillon and S. fluitans (Borgessen) Borgesen (brown algae), found offshore in Ondo State, Nigeria. African Journal of Biotechnology 13:1188-1193. DOI: 10.5897/AJB2013.12335

Påhlsson, A-M.B. 1989. Toxicity of heavy metals $(\mathrm{Zn}, \mathrm{Cu}, \mathrm{Cd}, \mathrm{Pb})$ to vascular plants. Water, Air, \& Soil Pollution 47: 287-319. DOI: 10.1007/BF00279329

Quiroz-Jiménez, J.D., Roy, P.D. 2017. Evaluation of geochemical data by two different XRF spectrometers in sediments from the Santiaguillo Basin (state of Durango, Mexico). Geofisica International 57: 305-315. ISSN 0016-7169

R Core team. 2019. R: A Language and Environment for Statistical Computing. R Foundation for Statistical Computing, Vienna, Austria. https:/www.R-project.org/

Reis, V.A.T., Duarte, A.C. 2018. Analytical methodologies for arsenic speciation in macroalgae: A critical review. TrAC-Trends in Analytical Chemistry 102: 170-184. DOI: 10.1016/j.trac.2018.02.003

Rodríguez-Martínez, R.E., Medina-Valmaseda, A.E., Blanchon, P., Monroy-Velázquez, L.V., Almazán-Becerril, A., Delgado-Pech, B., Vásquez-Yeomans, L., Francisco, V., García-Rivas, M.C. 2019. Faunal mortality associated with massive beaching and decomposition of pelagic Sargassum. Marine Pollution Bulletin 146: 201-205. DOI: 10.1016/j.marpolbul.2019.06.015

Rodríguez-Martínez, R.E., Ruíz-Rentería, F., van Tussenbroek, B., Barba-Santos, G., EscalanteMancera, E., Jordán-Garza, G., Jordán-Dahlgren, E. 2010. Environmental state and tendencies of the Puerto Morelos CARICOMP site, Mexico. Revista de Biología Tropical 58: 23-43. ISSN 0034-7744

Rodríguez-Martínez, R.E., van Tussenbroek, B., Jordán-Dahlgren, E. 2016. Afluencia masiva de sargazo pelágico a la costa del Caribe mexicano (2014-2015). In: Mendoza, E., Quijano- 
476

477

478

479

480

481

482

483

484

485

486

487

488

489

490

491

492

493

494

495

496

497

498

499

500

501

502

503

504

505

506

507

508

509

510

511

512

513

514

515

Scheggia, S.I., Olivos-Ortiz, A., Núñez-Vázquez, E.J. ed. Florecimientos Algales Nocivos en México. CICESE, Ensenada, México, pp. 352-365.

Ruiz Huerta, E.A., Armienta Hernández, M.A. 2012. Acumulación de arsénico y metales pesados en maíz en suelos cercanos a jales o residuos mineros. Revista Internacional de Contaminación Ambiental 28: 103-117.

Schell, J.M., Goodwin, D.S., Siuda, A.N.S. 2015. Recent Sargassum inundation events in the Caribbean: Shipboard observations reveal dominance of a previously rare form. Oceanography 28, 8-11.

SEDETUR. 2019. Indicadores Turísticos de Quintana Roo. México. Available at https://qroo.gob.mx/sedetur/indicadores-turisticos (accessed October 8, 2019).

Spalding, M., Burke, L., Wood, S.A., Ashpole, J., Hutchison, J., zu Ermgassen, P. 2017. Mapping the global value and distribution of coral reef tourism. Marine Policy 82: 104-113.

Takahashi, K., Blackwelder, P.L. 1992. The spatial distribution of silicoflagellates in the region of the Gulf Stream warm-core ring 82B: application to water mass tracer studies. Deep Sea Research Part A. Oceanographic Research Papers 39: S327-S346. DOI: 10.1016/S01980149(11)80018-X

van Tussenbroek, B.I., Hernández-Arana, H.A., Rodríguez-Martínez, R.E., Espinoza-Avalos, J., Canizales-Flores, H.M., González-Godoy, C.E., Barba-Santos, M.G., Vega-Zepeda, A., Collado-Vides, L. 2017. Severe impacts of brown tides caused by Sargassum spp. on nearshore Caribbean seagrass communities. Marine Pollution Bulletin 122: 272-281. DOI: 10.1016/j.marpolbul.2017.06.057

Volesky, B., Holan, Z.R. 1995. Biosorption of heavy metals. Biotechnology Progress 11: 235250. DOI: $10.1021 / \mathrm{bp} 00033 \mathrm{a} 001$

Wang, S., Cao, B., Abomohra, A.E-F., Hu, Y., Wang, Q., He, Z., Xu, S., Feng, Y., Bernard, U.B., Jiang, X. 2018. Comparative study of combustion properties of two seaweeds in a batch fluidized bed. Combustion Science and Technology 190: 755-769. DOI: 10.1080/00102202.2017.1407761

Wang, M., Hu, C., Barnes, B.B., Mitchum, G., Lapointe, B., Montoya, J.P. 2019. The great Atlantic Sargassum belt. Science 365: 83-87. DOI: 10.1126/science.aaw7912

Warnes, G.R., Bolker, B., Bonebakker, L., Gentleman, R. 2009. gplots: Various R programming tools for plotting data. $\mathrm{R}$ package version.

Weis, J.S. 1968. Fauna associated with pelagic Sargassum in the Gulf Stream. The American Midland Naturalist Journal 80: 554-558. DOI: 10.2307/2423550

Whelan, T. III, van Tussenbroek, B.I., Santos, M.G.B. 2011. Changes in trace metals in Thalassia testudinum after hurricane impacts. Marine Pollution Bulletin 62: 2797-2802. DOI: 10.1016/j.marpolbul.2011.09.007

Wickham, H. 2009. Elegant graphics for data analysis (ggplot2). Available at http://had.co.nz/ggplot2/book

Wickham, H. 2018. Reshape. Version 0.8.8. Available at https://CRAN.Rproject.org/package $=$ reshape

Peer) reviewing PDF | (2019:11:43362:1:1:CHECK 23 Jan 2020) 
516 Wickham, H., Henry, L. 2017.Tidyr: Easily tidy data with'spread ()'and'gather ()'functions. R 517 package version $0.6,1$

518 Wickham, H., François, R., Henry, L., Müller, K. 2019. dplyr package. Version 0.8.3. Available 519 at https://cran.r-project.org/web/packages/dplyr/index.html

520 Wu, H., Zhan, D., Liu, H., Ding, G., Liu, W., Li, M. 2010. Study on accumulation and degradation of heavy metals by the brown alga Sargassum thunbergii. Marine Sciences 34: 69-74.

Yu, Y.V. 2007. Marine Algal Constituents. In: Barrow, C., Shahidi, F. (eds). Marine 525 


\section{Table $\mathbf{1}$ (on next page)}

Samples information

Number of samples collected at eight sites along the Mexican Caribbean coast during 2018-2019. Habitat refers to distance from coast, shore (2-20 m from coast) or ocean ( $>5 \mathrm{~km}$ from coast). 


\begin{tabular}{|c|c|c|c|c|c|c|c|c|}
\hline \multirow[t]{2}{*}{ Locality } & \multirow[t]{2}{*}{ Habitat } & \multicolumn{2}{|l|}{ Collection } & \multicolumn{4}{|c|}{ Species/Morphotype } & \multirow[t]{2}{*}{ Total } \\
\hline & & Year & Month & Sflu III & Snat I & Snat VIII & Sarg sp & \\
\hline 1 - Contoy Island & Ocean & 2019 & March & & & & 4 & 4 \\
\hline 2 - Blue waters & Ocean & 2018 & August & & 1 & & & 1 \\
\hline \multirow[t]{7}{*}{3 - Puerto Morelos } & Shore & 2018 & August & 1 & 1 & 1 & & 3 \\
\hline & & & September & 1 & 1 & 1 & & 3 \\
\hline & & & October & 2 & 1 & 2 & & 5 \\
\hline & & & December & 1 & 1 & & & 2 \\
\hline & & 2019 & February & 2 & 2 & 2 & & 6 \\
\hline & & & March & 1 & 3 & 2 & & 6 \\
\hline & & & April & 1 & & 1 & & 2 \\
\hline \multirow[t]{2}{*}{4 - Cozumel } & Ocean & 2018 & August & & & 1 & & 1 \\
\hline & & 2019 & May & 1 & 1 & 1 & & 3 \\
\hline 5 - Mahahual & Shore & 2019 & May & 4 & 3 & & & 7 \\
\hline 6 - Chinchorro & Shore & 2019 & May & & 1 & & & 1 \\
\hline \multirow[t]{3}{*}{7 - Xahuayxol } & Shore & 2019 & April & 1 & 2 & & & \\
\hline & & & May & 2 & 1 & & & \\
\hline & & & June & 3 & 3 & & & \\
\hline 8 - Xcalak & Shore & 2019 & May & 3 & 3 & & & 6 \\
\hline Total & & & & 24 & 24 & 11 & 4 & 63 \\
\hline
\end{tabular}

Sarg sp: Sargassum spp., Sflu III: Sargassum fluitans III, Snat I: S. natans I, Snat VIII: S. natans VIII. 


\section{Table 2 (on next page)}

Element concentrations median and range

Element concentrations (ppm DW) of pelagic Sargassum spp. tissue collected from eight localities along the Mexican Caribbean coast between 2018 and 2019. The number of samples with readings above LOD are expressed in \% of the total sample size $(n=63)$. LOD: Limit of detection. 


\begin{tabular}{llllll}
\hline Element & LOD & $\begin{array}{l}\text { Samples with readings } \\
\text { above LOD }(\%)\end{array}$ & Minimum & Maximum & Median
\end{tabular}

\begin{tabular}{llllll}
\hline $\mathrm{Al}$ & 140 & 58.7 & $<$ LOD & 500 & 206 \\
$\mathrm{As}$ & 4 & 100 & 24 & 172 & 80 \\
$\mathrm{Ca}$ & 394 & 100 & 23,723 & 136,146 & 70,040 \\
$\mathrm{Cl}$ & 266 & 100 & 747 & 53,101 & 22,350 \\
$\mathrm{Cu}$ & 6 & 7.9 & $<$ LOD & 540 & $<$ LOD \\
$\mathrm{Fe}$ & 3 & 7.9 & $<$ LOD & 11 & $<$ LOD \\
$\mathrm{K}$ & 333 & 100 & 1,990 & 46,002 & 19,666 \\
$\mathrm{Mg}$ & 2915 & 92.1 & $<$ LOD & 13,662 & 6,537 \\
$\mathrm{Mn}$ & 13 & 100 & 40 & 139 & 71 \\
$\mathrm{Mo}$ & 1 & 9.5 & $<$ LOD & 7 & $<$ LOD \\
$\mathrm{P}$ & 145 & 100 & 228 & 401 & 327 \\
$\mathrm{~Pb}$ & 2 & 7.9 & $<$ LOD & 3 & $<$ LOD \\
$\mathrm{Rb}$ & 1 & 100 & 30 & 143 & 56 \\
$\mathrm{~S}$ & 199 & 100 & 9,462 & 24,773 & 14,363 \\
$\mathrm{Si}$ & 342 & 100 & 447 & 2,922 & 1,767 \\
$\mathrm{Sr}$ & 6 & 100 & 1,605 & 2,564 & 1,890 \\
$\mathrm{Th}$ & 1 & 100 & 5 & 23 & 10 \\
$\mathrm{U}$ & 4 & 27 & 11 & 48 & 23 \\
$\mathrm{~V}$ & 3 & 60.3 & $<$ LOD & 13 & $<$ LOD \\
$\mathrm{Zn}$ & 5 & 12.7 & $<$ LOD & 17 & $<$ LOD \\
\hline & & & & & \\
\hline
\end{tabular}




\section{Table 3 (on next page)}

Elements concentrations in sargasso morphotypes

Median and range (in parenthesis) of elements (ppm DW) in three sargasso species/morphotypes collected from eight localities along the Mexican Caribbean coast in 2018-2019. $P$ values show summary of statistical analyses using Kruskal-Wallis $H$ test (bold if significant) and the last column shows results of multiple comparison test. LOD: limit of detection. 


\begin{tabular}{|c|c|c|c|c|c|}
\hline \multicolumn{2}{|c|}{$\begin{array}{l}\text { Element a) } S \text {. fluitans III } \\
\qquad(\mathrm{n}=24)\end{array}$} & \multirow{2}{*}{$\begin{array}{l}\text { b) } \boldsymbol{S} . \text { natans I } \\
(\mathrm{n}=24) \\
198 \\
(<\mathrm{LOD}-500)\end{array}$} & \multirow{2}{*}{$\begin{array}{l}\text { c) } \boldsymbol{S} \text {. natans } \\
\text { VIII } \\
(\mathrm{n}=11) \\
<\mathrm{LOD} \\
(<\mathrm{LOD}-327)\end{array}$} & \multirow{2}{*}{$\begin{array}{l}\boldsymbol{P} \\
0.7341\end{array}$} & \multirow[t]{2}{*}{$\begin{array}{l}\text { Multiple comparison } \\
\text { test }\end{array}$} \\
\hline $\mathrm{Al}$ & $\begin{array}{l}221 \\
(<\mathrm{LOD}-392)\end{array}$ & & & & \\
\hline As & $\begin{array}{l}59 \\
(34-172)\end{array}$ & $\begin{array}{l}55 \\
(32-172)\end{array}$ & $\begin{array}{l}123 \\
(24-145)\end{array}$ & 0.0213 & $c>b$ \\
\hline $\mathrm{Ca}$ & $\begin{array}{l}76,727 \\
(46,599- \\
115,260)\end{array}$ & $\begin{array}{l}81,965 \\
(37,260- \\
136,146)\end{array}$ & $\begin{array}{l}43,289 \\
(23,723-75,849)\end{array}$ & 0.0013 & $(a=b)>c$ \\
\hline $\mathrm{Cl}$ & $\begin{array}{l}21,487 \\
(1,831-46,502)\end{array}$ & $\begin{array}{l}10,122 \\
(747-46,485)\end{array}$ & $\begin{array}{l}32,086 \\
(2,279-53,101)\end{array}$ & 0.0111 & $c>b$ \\
\hline $\mathrm{K}$ & $\begin{array}{l}19,466 \\
(3,620-44,280)\end{array}$ & $\begin{array}{l}14,309 \\
(1,990-39,642)\end{array}$ & $\begin{array}{l}32,900 \\
(4,902-46,002)\end{array}$ & 0.0121 & $c>b$ \\
\hline $\mathrm{Mg}$ & $\begin{array}{l}6,376 \\
(2,062-12,325)\end{array}$ & $\begin{array}{l}6,385 \\
(2,062-12,949)\end{array}$ & $\begin{array}{l}6,883 \\
(2,062-13,662)\end{array}$ & 0.5990 & \\
\hline $\mathrm{Mn}$ & $\begin{array}{l}70 \\
(51-112)\end{array}$ & $\begin{array}{l}89 \\
(52-139)\end{array}$ & $\begin{array}{l}56 \\
(40-135)\end{array}$ & 0.0019 & $\mathrm{~b}>(\mathrm{a}=\mathrm{c})$ \\
\hline $\mathrm{P}$ & $\begin{array}{l}336 \\
(229-401)\end{array}$ & $\begin{array}{l}328 \\
(262-394)\end{array}$ & $\begin{array}{l}300 \\
(228-350)\end{array}$ & 0.0590 & \\
\hline $\mathrm{Rb}$ & $\begin{array}{l}60 \\
(32-102)\end{array}$ & $\begin{array}{l}51 \\
(30-143)\end{array}$ & $\begin{array}{l}67 \\
(48-120)\end{array}$ & 0.0071 & $c>b$ \\
\hline $\mathrm{S}$ & $\begin{array}{l}14,341 \\
(11,328-24,773)\end{array}$ & $\begin{array}{l}12,776 \\
(9,462-21,170)\end{array}$ & $\begin{array}{l}16,231 \\
(12,449-19,500)\end{array}$ & 0.1370 & \\
\hline $\mathrm{Si}$ & $\begin{array}{l}1,861 \\
(927-2,877)\end{array}$ & $\begin{array}{l}2,095 \\
(696-2,564)\end{array}$ & $\begin{array}{l}1,049 \\
(447-2,135)\end{array}$ & 0.0009 & $(a=b)>c$ \\
\hline $\mathrm{Sr}$ & $\begin{array}{l}1,934 \\
(1,641-2,395)\end{array}$ & $\begin{array}{l}1,876 \\
(1,605-2,564)\end{array}$ & $\begin{array}{l}1,793 \\
(1,633-2362)\end{array}$ & 0.4375 & \\
\hline $\mathrm{Th}$ & $\begin{array}{l}10 \\
(5-17)\end{array}$ & $\begin{array}{l}8 \\
(6-23)\end{array}$ & $\begin{array}{l}9 \\
(8-20)\end{array}$ & 0.3021 & \\
\hline $\mathrm{U}$ & $\begin{array}{l}22 \\
(11-48)\end{array}$ & $\begin{array}{l}23 \\
(12-47)\end{array}$ & $\begin{array}{l}27 \\
(16-45)\end{array}$ & 0.2321 & \\
\hline
\end{tabular}




\section{Table 4(on next page)}

Element concentrations in different studies

Comparison of element concentration in sargasso from the Mexican Caribbean coast and other studies in different parts of the world. 


\begin{tabular}{|c|c|c|c|c|}
\hline Element & $\begin{array}{l}\text { Site (Year) } \\
\text { Nigeria }^{a} \\
(2012) \\
\end{array}$ & $\begin{array}{l}\text { Dominican Republic }{ }^{b} \\
(2015)\end{array}$ & $\begin{array}{l}\text { Ghana }^{\mathrm{c}} \\
(2015)\end{array}$ & $\begin{array}{l}\text { Mexican Caribbean } \\
(2018-2019)\end{array}$ \\
\hline $\mathrm{Al}$ & & $303-4,188$ & & $<140-517$ \\
\hline As & & $14-42$ & $13-54$ & $24-172$ \\
\hline $\mathrm{Ba}$ & & $7-17$ & & $<36$ \\
\hline $\mathrm{Ca}$ & & $96,901-133,400$ & & $23,723-136,146$ \\
\hline $\mathrm{Cd}$ & & $0.1-0.3$ & $78-119$ & $<2$ \\
\hline $\mathrm{Cl}$ & & & $61-1353$ & $747-53,101$ \\
\hline Co & & $0.4-1$ & & $<11$ \\
\hline $\mathrm{Cr}$ & & $2-56$ & & $<8$ \\
\hline $\mathrm{Cu}$ & & $2-12$ & $24-36$ & $<6-540$ \\
\hline $\mathrm{Fe}$ & $8,700 \pm 280$ & $20-655$ & $1,209-5,910$ & $<3-11$ \\
\hline K & $28,000 \pm 740$ & $2,208-33,602$ & & $1,990-46,002$ \\
\hline $\mathrm{Mg}$ & $42,750 \pm 3,500$ & $10,211-18,241$ & & $<2915-13,662$ \\
\hline $\mathrm{Mn}$ & & $16-32$ & & $40-139$ \\
\hline Mo & & $0.6-3$ & & $<1-7$ \\
\hline $\mathrm{Ni}$ & & $10-33$ & & $<10$ \\
\hline $\mathrm{P}$ & $96,500 \pm 21,200$ & $761-1,145$ & & $228-401$ \\
\hline $\mathrm{Pb}$ & & $1-2$ & $105-335$ & $<2-3$ \\
\hline $\mathrm{Rb}$ & & $0.3-10$ & & $30-143$ \\
\hline $\mathrm{Si}$ & & $23,883-55,776$ & & $447-2,922$ \\
\hline $\mathrm{Sr}$ & & $1,162-1,437$ & & $1,605-2,564$ \\
\hline Th & & $0.04-0.4$ & & $5-23$ \\
\hline $\mathrm{Ti}$ & & $37-92$ & & $<29$ \\
\hline $\mathrm{U}$ & & $0.2-0.7$ & & $11-48$ \\
\hline $\mathrm{V}$ & & $1-3$ & & $<3-13$ \\
\hline $\mathrm{Y}$ & $40 \pm 0.0$ & $0.1-0.8$ & & $<1$ \\
\hline $\mathrm{Zn}$ & $50 \pm 0.0$ & $13-21$ & $16-100$ & $<5-17$ \\
\hline $\mathrm{Zr}$ & & $8-34$ & & $<2$ \\
\hline
\end{tabular}

1 a Oyesiku \& Egunyomi, 2014 (mean and SD); ${ }^{\mathrm{b}}$ Fernández et al., 2017 (range); ${ }^{\mathrm{c}}$ Dzama-Addico 2 \& deFraft-Johnson, 2016 (range); ${ }^{\mathrm{d}}$ This study (range) 
Figure 1

Sampling sites

Location of the sampling sites of sargasso along the Mexican Caribbean coast between August 2018 and June 2019. Map produced in QGIS 2.18 (www.qgis.org) using the following data sources: National Geospatial-Intelligence Agency (base map, World Vector Shoreline Plus, 2004. http://shoreline.noaa.gov/data/datasheets/wvs.html). The location of survey sites was obtained from the present study. Data sources are open access under the Creative Commons License (CC BY 4.0). 


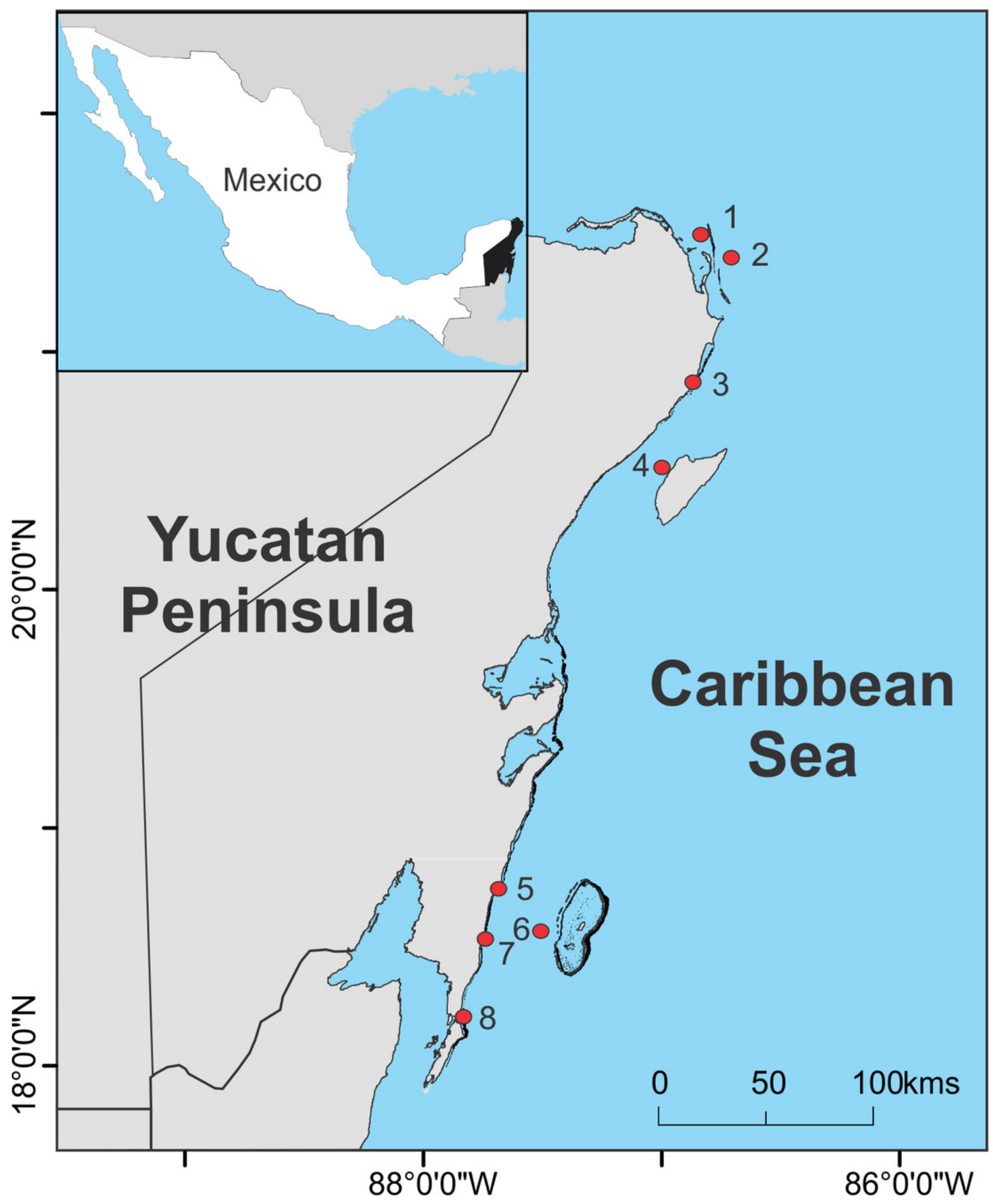




\section{Figure 2}

Spatial variability in element concentrations

Concentration of fourteen most frequent elements (ppm algal DW) in tissues of sargasso collected at eight sites along the Mexican Caribbean coast in 2018-2019. Note differences in scale of the Y-axis. Each dot corresponds to the median of the five XRF readings per sample. Color of the dot represents the sargasso species/morphotype. The horizontal black lines correspond to the median for each site. The dotted blue line corresponds to the limit of detection of the XRF equipment. A: Aluminum, B: Arsenic, C: Calcium, D: Chlorine, E: Potassium, F: Magnesium, G: Manganese, H: Phosphorus, I: Rubidium, J: Sulphur, K: Silicon, L: Strontium, M: Thorium, N: Uranium. Figure 1 and Table 1 have the site and sample details. 

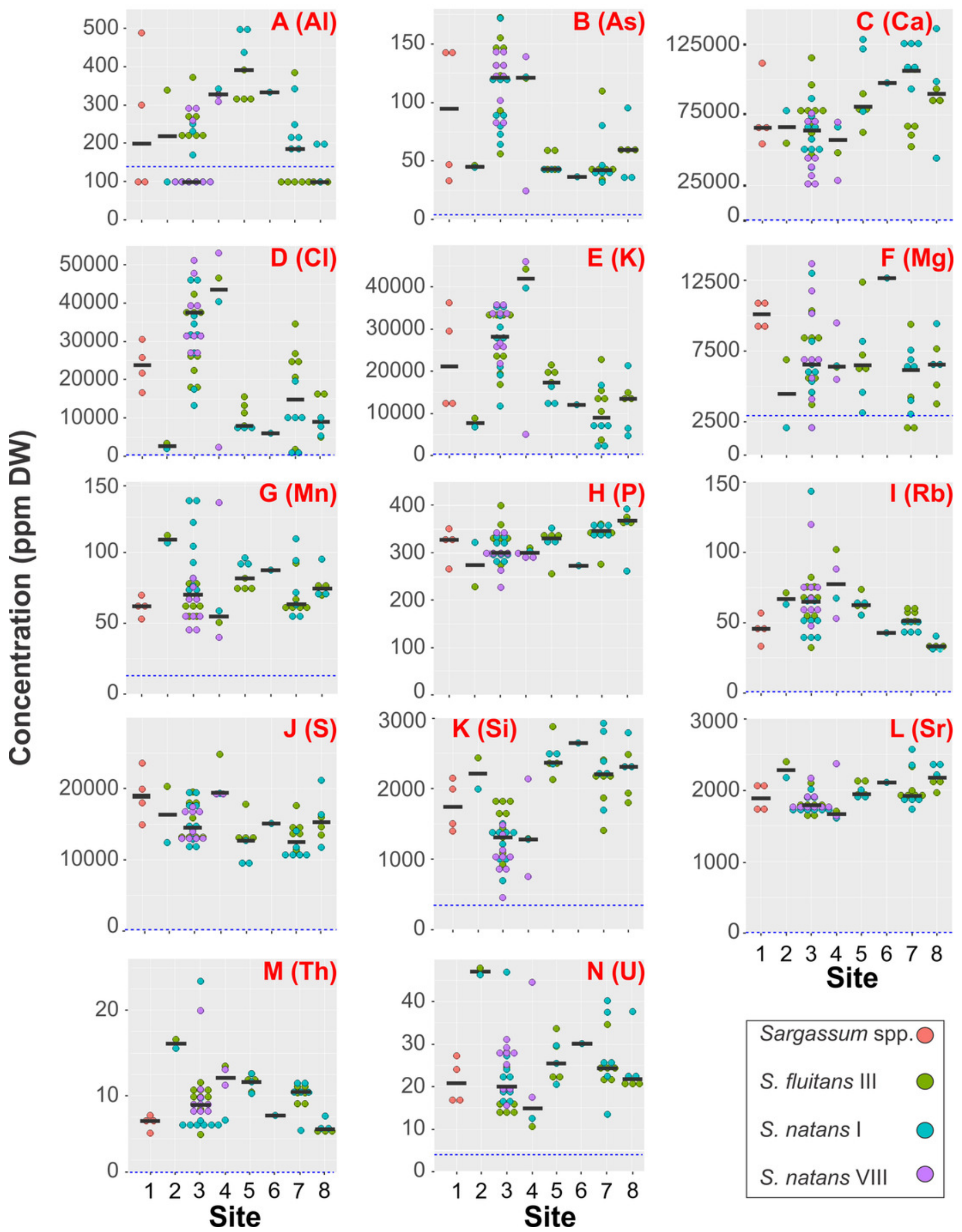

$\begin{array}{llll}12 & 345678 \\ \text { Site } & \end{array}$

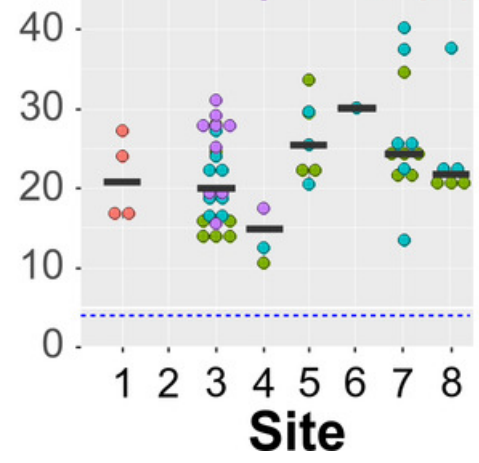

\begin{tabular}{lr}
\multicolumn{2}{l|}{ Sargassum spp. } \\
S. fluitans III & $\bigcirc$ \\
S. natans I & $\bigcirc$ \\
S. natans VIII & $\bigcirc$
\end{tabular}




\section{Figure 3}

Temporal variability in element concentrations

Variability in concentration of fourteen different elements (ppm DW) in sargasso collected at Puerto Morelos between August 2018 and April 2019. Z-score transformations were applied to values of each element across all the sampling periods and their intensities above and below the mean are represented on the heatmap by red and yellow colors respectively, as shown on the color key bar. 


\section{Color Key$$
-2-1 \quad 0 \quad 12
$$ \\ Value}

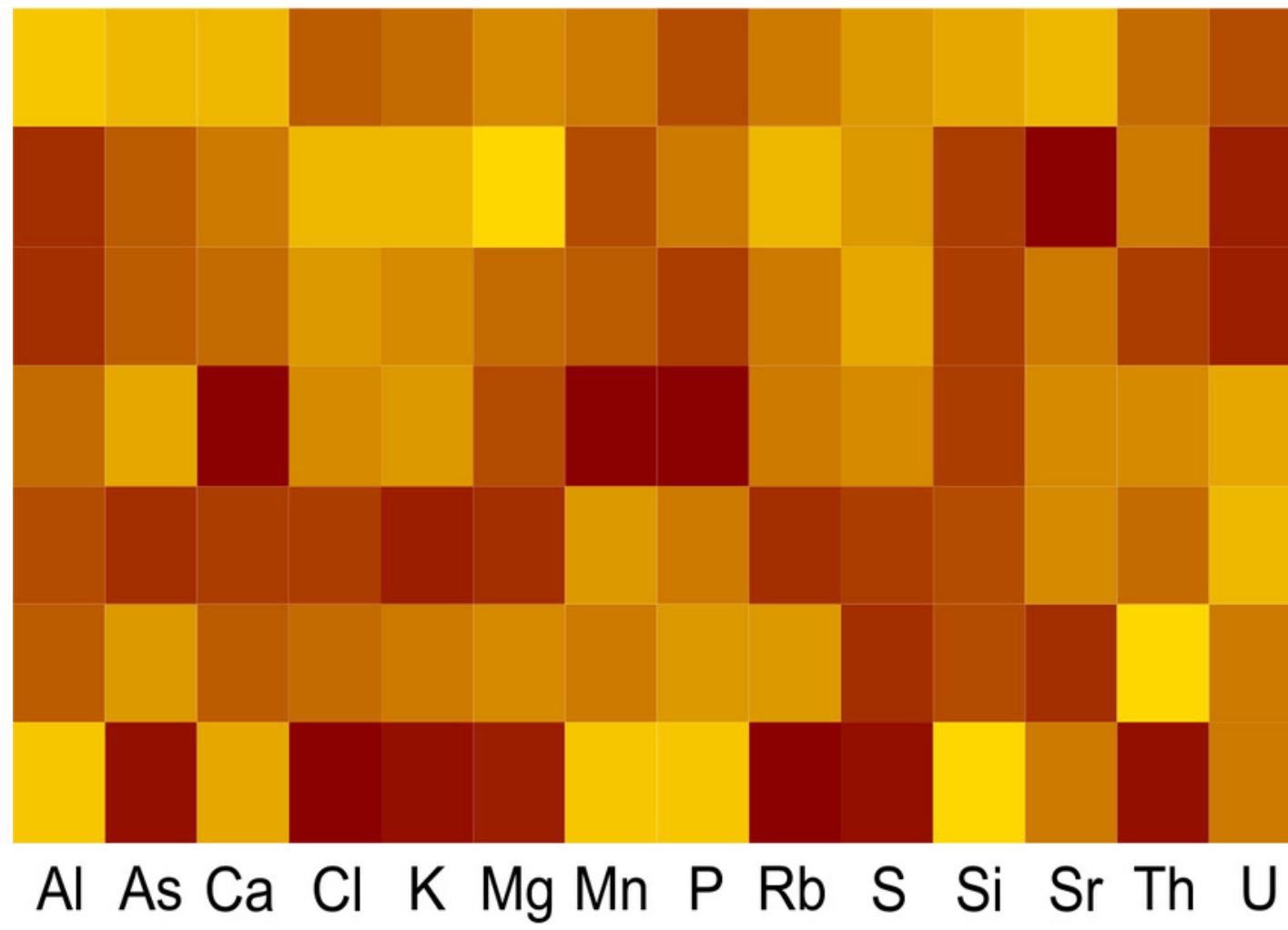

Aug-2018

Sep-2018

Oct-2018

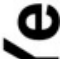

Dec-2018

Feb-2019

Mar-2019

Apr-2019

Element 